\title{
Audit Fees and Financial Reporting Quality: A Study of Listed Companies in Nigeria
}

\author{
HUSSAINI BALA \\ Department of Accounting, Kaduna State University, Nigeria \\ Tel: +2348036943413 \\ Email: hussainumi2013@gmail.com
}

NOOR AFZA AMRAN

Associate Professor Tunku Puteri Intan Safinaz School of Accountancy (TISSA-UUM), Universiti Utara Malaysia, 06010 Sintok, Kedah, Malaysia.

\section{HASNAH SHAARI}

Senior Lecturer Tunku Puteri Intan Safinaz School of Accountancy (TISSA-UUM), Universiti Utara Malaysia, 06010 Sintok, Kedah, Malaysia.

\begin{abstract}
This paper examines the relationship between audit fees and financial reporting quality of listed firms in Nigeria. We use 88 listed companies in Nigeria for the period of 2012 to 2016. The data were obtained from the annual reports of the listed firms and Thompson Reuters DataStream. Accruals model was used to represent financial reporting quality. A multiple regression was employed in the estimation model. The study reveals that higher audit fees are associated to lower level of discretionary accruals and thus imply higher financial reporting quality. The result also supports the resource dependence theory which proposes that higher percentage of financial experts in the board lessen the degree of accounting manipulation. The study provides an understanding to investors, policymakers and regulators about the pivotal role of audit fees in reducing accounting manipulation and in enhancing financial reporting quality in the listed firms in Nigeria.
\end{abstract}

Keywords: Audit Fees, Discretionary Accruals, Financial Reporting Quality.

\section{Introduction}

Financial reporting quality signifies the degree to which financial reports provide truthful and unbiased information about core financial positions and financial performance (FASB). Thus, understanding financial reporting quality is worthwhile to the investor, who needs to effectively evaluate investment risk in the international capital markets (Tang, Chen, \& Lin, 2016). It is argue that the quality of financial reports is determined by the value of accounting earnings (Herath \& Albarqi, 2017). Consequently, it is apparently important to provide superior financial reporting quality to protect users in making rational investments choices, and to enrich market efficiency. Thus, audit quality is an incessant paradigm that guarantees financial reporting quality, as greater quality auditing provides better assurance of higher quality financial reporting (DeFond \& Zhang, 2014). In that, audit quality improves financial reporting quality through enhancing the reliability of financial reports. However, prior studies argue that audit fees can a better construct for audit quality and thus enhances financial reporting quality of firms (DeFond \& Zhang, 2014; Gaynor, Kelton, Mercer, \& Yohn, 2016). This is because audit fees is assumed to accelerate audit 
efforts which is associated to greater audit coverage and thus leading for better financial reporting quality (Abbott, Parker, Peters, \& Raghunandan, 2003; DeFond \& Zhang, 2014; Molly Mercer, 2016; Gaynor et al., 2016; Mitra, Deis, \& Hossain, 2009).

This study aims to examine the influence of audit fees on financial reporting quality of listed firms in Nigeria. This is motivated by the recent increase and dominance of Big 4 auditors in the auditors' market concentration in Nigeria which will directly affect the fees paid to external auditors by their client. Thus, companies that were audited by the Big 4 auditors pay an excessively higher remuneration than the companies audited by Non-Big 4 auditors (Asien, 2014). The paper is divided into five sections. Section one presents the introduction, section two gives the literature and hypothesis development, section three describes the methodology and model specification, then followed by results and discussions and finally conclusion.

\section{Literature and Hypothesis Development}

\section{Audit Fees and Financial Reporting Quality}

The extent of the audit fee is basically elucidated by client attributes related to audit effort and audit risk (Turpen, 1995). Previous studies document that higher audit fees are related to lesser earnings management and higher financial reporting quality. For instance, Franke, Johnson and Nelson (2002) study the effect of audit fees and earnings management in US. The study reveals that audit fees have a negative significant relationship with earnings management. This is affirmed by Hoitash, Markelevich and Barragato (2007) who apply 13,860 firm-year observations and determine the influence of audit fees and audit quality in US. Their finding reveals a negative significant correlation between audit fees and discretionary accruals. Mitra, Deis and Hossain (2009) examine the relationship between audit fees and FRQ of Big 5 client firms in US. They employ a sample of 6,852 firm- year observations for the period of 2000 to 2005 . Their finding reveals that audit fees reduce the likelihood of abnormal accruals and thus increase earnings quality. More so, Carmona, Momparler and Lassala (2015) explore the relationship between audit fees and audit quality of listed firms in Spain. They show that audit fee is negatively and significantly related to discretionary accruals. This indicates that higher audit price is related lower discretionary accruals and higher financial reporting quality.

More recently Asthana, Khurana and Raman (2018) examine fees competition amongst Big 4 auditors and audit quality in US. They show that fees competitions are valued as essential mechanism for enhancing audit quality in the vastly concentrated US audit market. In the same vain, Knechel, Mintchik, Pevzner and Velury (2018) examine the impacts of widespread trust and community cooperation on audit fees amongst different countries in the world. They reveal that countries with higher trust and community cooperation have high likelihood to expense on a strong audit job to request higher auditing services. They argue that countries with greater trust and community cooperation reimburse higher audit fees to demand greater assurance. This indorses that countries with higher extensive trust or greater public cooperation pay higher price on auditing services and hence are prepared to pay higher audit fees.

From the emerging market, Al-Dhamari Al-Gamrh Ismail and Ismail (2018) explore the link between related party transactions and audit fees in Malaysia. They indicate that audit fees are high for firms that engage in related party transactions including the acquisition and sale of assets, goods, and services. This validates the finding of Al-Rassas and Kamardin (2015) who study the influence of external audit quality and audit committee characteristics in Malaysia. They show that audit fee has a negative and significant relationship with discretionary accruals. This suggests that higher audit fees is associated to lower discretionary and higher financial reporting quality in Malaysia. This is affirmed by Nawaiseh (2016) who study the influence of external auditors on earnings management in Jordan. She shows that audit fees have a negative significant association with discretionary accruals. On one hand, Aliyu, Musa, and Zachariah (2015) examine the association between audit quality and earnings management in Nigeria. They use a 
sample of listed banks for the year 2006 to 2013 . They show that audit fee is positively and significantly associated to abnormal loan loss provision. This shows that auditors' monetary dependence raises the rate of earnings management practice in Nigerian banks. On the other hand, Eriabie and Dabor (2017) study the relationship between audit quality and earnings management in Nigeria. They employ a sample of 18 listed banks for the year 2005 to 2010 . Their finding reveals that audit quality is negatively associated to earnings management. This is confirmed by Ndubuisi and Ezechukwu (2017) who study the determinants of audit quality amongst Nigerian Banks. They show that higher audit fees have high likelihood of increasing audit quality. Okolie (2014) examine the effects of auditors' independence on earnings management. They use a sample of 57 listed companies in Nigeria for the period of 2006 to 2011. The finding indicates that audit fee has a negative significant and association with discretionary accruals. This is affirmed by AbdulMalik and Che-Ahmad (2016) who explore the impact of audit fees on financial reporting quality in Nigeria. The source data from the annual reports of 89 listed companies for the periods of 2008 to 2013 . They show that audit fees have a negative significant influence on discretionary accruals. They further suggest that extreme fees paid to auditors in Nigeria may not impair their independence since it reduces the magnitude of abnormal accruals. In addition recent study of Abdul-Rahman, Benjamin and Olayinka (2017) who examine the relationship between of audit fees and quality of audit in Nigeria reveals that audit fee is positive and significantly related to audit quality. From foregoing argument, the study hypothesized that: $\mathrm{H}_{1}$ Audit fee has a positive significant relationship with financial reporting quality.

\section{Methodology}

The population of this study covers 170 listed companies in the Nigerian Stock Exchange as at $31^{\text {st }}$ December 2016. We exclude 55 companies from the financial services leaving a total of 115 companies. Moreover we remove 15 companies that were delisted by the Nigerian Stock Exchange in 2016. Thus, leaving a total of 100 companies. From these 100 companies, 12 of them did not provide adequate information on the variables of interest. Therefore, a final sample of 88 firms was adopted. The period of study ranges from 2012 to 2016 . We extract data from the annual reports of the listed firms and Thompson Reuters DataStream.

\section{Model Specification Variable Measurement}

Following Abdullah and Ismail (2016), Al-Rassas and Kamardin (2015) we employ Kothari, Leone and Wasley (2005) to function as a method for identifying financial reporting quality. The error terms from the model represent the absolute discretionary accruals. This is estimated as;

$\mathrm{TAC}_{\mathrm{i}, \mathrm{t}} / \mathrm{TA}_{\mathrm{i}, \mathrm{t}-1}=\beta_{1}\left(1 / \mathrm{TA}_{\mathrm{i}, \mathrm{t}-1}\right)+\beta_{2}\left(\Delta \mathrm{REV}_{\mathrm{i}, \mathrm{t}}-\Delta \mathrm{REC}_{\mathrm{i}, \mathrm{T}} / \mathrm{TA}_{\mathrm{i}, \mathrm{t}-1}\right)+\beta_{3}\left(\Delta \mathrm{PPE}_{\mathrm{i}, \mathrm{T}} / \mathrm{TA}_{\mathrm{i}, \mathrm{t}-1}\right)+\beta_{4} \mathrm{ROA}_{\mathrm{i}, \mathrm{t}-1}+$

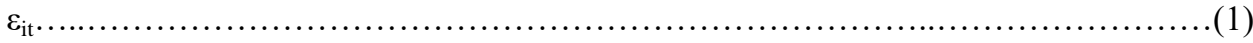

Where; $\mathrm{TAC}=$ Total accruals calculated as net earnings - cash flow from operation, $\mathrm{TA}_{\mathrm{i}, \mathrm{t}-1}=$ Lagged of total assets of a company, $\triangle \mathrm{REV}=$ changes in revenue from current year to last year, $\triangle \mathrm{REC}=$ changes in receivables from current year to last year, $\mathrm{PPE}=$ gross property plant and equipment and $\mathrm{ROA}=$ Return on asset.

After the residual (discretionary accruals) was extracted from the above equation (1), following estimation model was run to examine the impact of audit fees on financial reporting quality.

$\mathrm{DAC}_{\text {it }}=\beta 0+\beta_{1} \mathrm{AUFEE}_{\mathrm{it}}+\beta_{2} \mathrm{BID}_{\mathrm{it}}+\beta_{3} \mathrm{BEF}_{\mathrm{it}}+\beta_{4} \mathrm{LEV}_{\mathrm{it}}+\beta_{5} \mathrm{FAGE}_{\mathrm{it}} \beta_{6} \mathrm{SGROW}_{\mathrm{it}}$

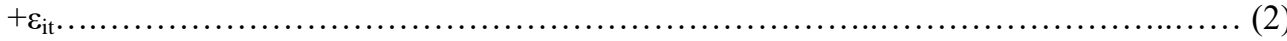

Where; DAC $=$ absolute discretionary accruals, AUFEE $=$ audit fees measured as natural logarithm of audit fees, BID = board independence calculated as percentage of independent directors on the board, BEF = board financial expertise calculated as percentage of financial experts on the board, LEV = leverage 
calculated as long term debt to total equity, FAGE = calculated as year of observation minus year of listing, SGROW $=$ Sales growth calculated as current of sales divide by change in sales, $\beta 0=$ constant, $\beta=$ coefficient, $\mathrm{i}=$ firm, $\mathrm{t}=$ time and $\varepsilon=$ error term.

\section{Results and Discussions}

\section{Descriptive Statistics}

Table 1 represents the descriptive statistics of the variables. Table 1 reveals a mean of absolute discretionary accruals to the tone of 2.266 with the minimum (0.01) and maximum (5.903) respectively. It is shown that AUFEE has an average value of 27 million Naira (equivalent to 76,000 USD). This specifies that on regular basis listed firms in Nigeria pay up to 76,000 USD for audit services. It is shown that BID has an average value of $72 \%$ through a minimum and maximum ratio of $60 \%$ and $92 \%$ respectively. BEF has a mean ratio of $50 \%$ with the smallest and largest ratio of $25 \%$ and $75 \%$ respectively. This suggests that $50 \%$ of board members of listed firms in Nigeria are financial experts. LEV scores an average and highest ratios of $1.1 \%$ and $7.2 \%$ respectively. Firm age has an average number of 24 years through a minimum and maximum of 4 to 42 years respectively. SGROW reveal a mean figure of 0.270 and a minimum and maximum of -5.256 and 7.508 respectively. Table 1 finally reveals that majority of the listed firms in Nigeria engage the services of Big 4 auditors.

Table 1 Descriptive Statistics

\begin{tabular}{|llllll|}
\hline Variable & Obs & Mean & Std. Dev. & Min & Max \\
\hline DAC & 440 & 2.266 & 1.134 & 0.010 & 5.903 \\
AUFEE('000) & 440 & 27427 & 38879 & 2000 & 156178 \\
BID & 440 & 0.715 & 0.101 & 0.600 & 0.923 \\
BEF & 440 & 0.501 & 0.140 & 0.250 & 0.750 \\
FS & 440 & 16.422 & 1.592 & 13.755 & 19.450 \\
LEV & 440 & 0.011 & 0.019 & 0.000 & 0.072 \\
SGROW & 440 & 0.270 & 2.636 & -5.256 & 7.508 \\
FAGE & 440 & 23.818 & 13.288 & 4.000 & 42.000 \\
Big4 & 440 & 0.580 & 0.494 & 0.000 & 1.000 \\
\hline
\end{tabular}

Note: $\mathrm{DAC}=$ discretionary accruals, $\mathrm{AUFEE}=$ audit fees, $\mathrm{BID}=$ board independence, $\mathrm{BEF}=$ board financial expertise, FS = firm size, LEV = leverage, FAGE = firm age, SGROW = sales growth, Big4 = (KPMG, Price Waterhouse Coopers, Ernst \& Young and Deloitte).

\section{Correlation}

Table 2 presents the correlation matrix of the variables. Table 2 shows that AUFEE has a negative significant correlation with the absolute discretionary accruals at $5 \%$ significant level. Consequently, this signifies primary evidence about the direction of their association in the estimation model. It is also shown that BEF has a negative significant correlation with DAC at 5\% level of significance. However, BID, FS, LEV, SGROW and FAGE are all positively but insignificantly correlated with DAC. Big 4 auditors have a positive but insignificant correlation with DAC. Finally, the outcomes of the VIF test in Table 3 shows the tolerance values and the variance inflation factor of less than 1 and less than 10 respectively, suggesting that multicolinearity could not pose threat to the study (Gujarati, 2004) 
Table 2 Correlation Matrix

\begin{tabular}{|llllllllll|}
\hline Variable & DAC & AUFEE & BID & BEF & FS & LEV & SGROW & FAGE & BIG4 \\
\hline DAC & 1.000 & & & & & & & & \\
AUFEE & $-0.129^{* *}$ & 1.000 & & & & & & & \\
BID & -0.064 & 0.018 & 1.000 & & & & & & \\
BEF & $-0.126^{* *}$ & $0.318^{* * *}$ & $0.175^{* * *}$ & 1.000 & & & & & \\
FS & -0.020 & $0.681^{* * *}$ & $-0.0983^{*}$ & $0.265^{* * *}$ & 1.000 & & & & \\
LEV & -0.017 & 0.004 & 0.050 & 0.037 & -0.040 & 1.000 & & & \\
SGROW & -0.003 & -0.020 & 0.039 & $-0.133^{* *}$ & $-0.144^{* *}$ & -0.030 & 1.000 & & \\
FAGE & -0.030 & $0.142^{* *}$ & 0.047 & $0.130^{* *}$ & $0.172^{* * *}$ & 0.054 & $-0.0964^{*}$ & 1.000 & \\
Big4 & 0.023 & $0.212^{* * *}$ & $0.0937^{*}$ & $0.190^{* * *}$ & $0.174^{* * *}$ & -0.003 & -0.059 & 0.067 & 1.000 \\
\hline
\end{tabular}

Note: $\mathrm{DAC}=$ discretionary accruals, AUFEE $=$ audit fees, $\mathrm{BID}=$ board independence, $\mathrm{BEF}=$ board financial expertise, FS = firm size, $\mathrm{LEV}=$ leverage, $\mathrm{FAGE}=$ firm age, $\mathrm{SGROW}=$ sales growth, Big4 = (KPMG, Price Waterhouse Coopers, Ernst \& Young and Deloitte).

Table 3 Collinearity Diagnostic

\begin{tabular}{|ccc|}
\hline Variable & VIF & Tolerance \\
\hline AUFEE & 1.460 & 0.683 \\
BID & 1.110 & 0.904 \\
BEF & 1.220 & 0.821 \\
FS & 1.620 & 0.617 \\
LEV & 1.250 & 0.801 \\
SGROW & 1.070 & 0.934 \\
FAGE & 1.060 & 0.942 \\
Big4 & 1.080 & 0.924 \\
Mean VIF & 1.230 & \\
\hline
\end{tabular}

Note: AUFEE $=$ audit fees, $\mathrm{BID}=$ board independence, $\mathrm{BEF}=$ board financial expertise, $\mathrm{FS}=$ firm size, LEV $=$ leverage, FAGE $=$ firm age, $\mathrm{SGROW}=$ sales growth Big4 $=(\mathrm{KPMG}$, Price Waterhouse Coopers, Ernst \& Young and Deloitte).

\section{Regression Results}

Table 4 portrays the regression outcomes of the relationship between audit fees and financial reporting quality proxy by DAC. It is inferred from Table 4 that AUFEE reveals a negative significant relationship with DAC. This is shown from Table 4 which reveals a beta coefficient and p-value of -0.196 and 0.008 respectively. This implies that a unit increase in AUFEE decreases the magnitude of discretion accrual in the financial reports of listed firms in Nigeria and thus enhances financial reporting quality.

The result is consistent with the research hypothesis that AUFEE has a positive significant association with financial reporting quality of listed firms in Nigeria. It is in line with the premise that higher audit fees increases audit efforts and thus improves financial reporting process. The result validates the finding of previous studies who document that higher audit fees are related to lesser earnings management and higher financial reporting quality (Al-Rassas \& Kamardin, 2015; Franke et al., 2002; Hoitash et al., 2007; Mitra et al., 2009). 
Table 4 Relationship between Audit fees and Financial Reporting quality

\begin{tabular}{|lllll|}
\hline DAC & Coef. & $\begin{array}{l}\text { Robust } \\
\text { Std. Err. }\end{array}$ & t-values & p-values \\
\hline AUFEE & -0.196 & 0.074 & $-2.660^{* * *}$ & 0.008 \\
BID & -0.363 & 0.427 & -0.850 & 0.396 \\
BEF & -0.729 & 0.416 & $-1.750^{*}$ & 0.080 \\
FS & 0.091 & 0.054 & $1.670^{*}$ & 0.095 \\
LEV & 0.001 & 0.021 & 0.030 & 0.975 \\
SGROW & -0.001 & 0.004 & -0.280 & 0.782 \\
FAGE & 0.151 & 0.107 & 1.410 & 0.159 \\
Cons & 3.207 & 0.684 & $4.690^{* * *}$ & 0.000 \\
Hettest: F-val. & 0.160 & & & \\
\multicolumn{1}{r}{ P-vaue } & 0.690 & & & \\
Linktest: F-val. & 12.400 & & & \\
_hatsq & 0.113 & & & \\
\hline
\end{tabular}

Note: DAC $=$ discretionary accruals, AUFEE $=$ audit fees, $\mathrm{BID}=$ board independence, $\mathrm{BEF}=$ board financial expertise, FS = firm size, LEV = leverage, FAGE = firm age, SGROW = sales growth, Big4 = (KPMG, Price Waterhouse Coopers, Ernst \& Young and Deloitte).

Table 4 also shows that BEF is negatively and significantly related to DAC. Thus, the finding supports the resource dependence theory and agency theory which endorses that high percentage of financial experts in the board is a vital instruments for board monitoring because it leads to a healthier financial reporting quality (Pfeffer \& Salancik, 2003). However, FS reveals a positive significant relationship with DAC. This suggests that larger firms are more likely to engage in accounting manipulation in form of discretionary accruals. The result is in line with the findings of previous studies who report positive relationship between FS and DAC (Bartov, Givoly, \& Hayn, 2002; Chen, Sun, \& Wu, 2010; Nelson \& Devi, 2013). Other control variables BID, LEV, FAGE and SGROW are found to have insignificant relations with DAC.

\section{Conclusion}

Accrual model is part of the prominent measures employed to determine the degree of earnings manipulations. This model presumes that managers use discretionary accruals to architecture financial information to suit their desires which lower the quality of earnings. Consequently, this paper examines the relationship between audit fees and financial reporting quality represented by discretionary accruals. We employ a sample of 88 listed firms in Nigeria. The study documents that higher audit fees are associated to lower level of discretionary accruals and thus imply higher financial reporting quality. The finding also supports the resource dependence theory which recommends that higher ratio of financial experts in the board lessen the degree of accounting manipulation. The study offers an understanding to investors, policymakers and regulators about the significant role of audit fees in reducing accounting manipulation and in enhancing financial reporting quality in the listed firms in Nigeria.

\section{References}

Abbadi, S.S., Hijazi Q.F., \& Al-Rahahleh, A. (2016). Corporate governance quality and earnings management: Evidence from Jordan. Australasian Accounting, Business and Finance Journal, 10(2), $54-75$.

Abbott, L., Parker, S., Peters, G., \& Raghunandan, K. (2003). An empirical investigation of audit fees, nonaudit fees, and audit committees. Contemporary Accounting Research, 20(2), 215-234. 
https://doi.org/10.1506/8yp9-p27g-5nw5-djkk

Abdul-Rahman, O.A., Benjamin, O.A., \& Olayinka, O. H. (2017). Effect of audit fees on audit quality: Evidence from cement manufacturing companies in Nigeria. European Journal of Accounting, Auditing and Finance Research, 5(1), 6-17.

Abdullah, S. N. \& Ku Ismail, K. N. I. (2016). Women directors, family ownership and earnings management in Malaysia Shamsul. Asian Review of Accounting, 24(4), 1-47. https://doi.org/10.1108/ARA-04-2012-0017

AbdulMalik, S., \& Ahmad, A. C. (2016). Audit fees, corporate governance mechanisms and financial reporting quality in Nigeria. DLSU Business \& Economics Review, 26(1), 1-14.

Al-Dhamari, R. A., Al-Gamrh, B., Ismail, K. N. I. K., \& Ismail, S. S. H. (2018). Related party transactions and audit fees : the role of the internal audit function. Journal of Management \& Governance, 22(1), 187-212. https://doi.org/10.1007/s10997-017-9376-6

Al-Rassas, A. H., \& Kamardin, H. (2015). Internal and external audit attributes, audit committee characteristics, ownership concentration and earnings quality: Evidence from Malaysia. Mediterranean Journal of Social Sciences, 6(3), 458-470. https://doi.org/10.5901/mjss.2015.v6n3p458

Asien, E. N. (2014). Exploring the state of the audit market in Nigeria. African Journal of Accounting, Auditing and Finance, 3(4), 287-307.

Asthana, S., Khurana, I., \& Raman, K. K. (2018). Fee competition among Big 4 auditors and audit quality. Review of Quantitative Finance and Accounting, 50, 1-36. https://doi.org/10.1007/s11156-018-0714-9

Barton, J., \& Simko, P. J. (2002). The balance sheet as an earnings management constraint. The Accounting Review, 77(Supplement), 1-27. https://doi.org/10.2308/accr.2002.77.s-1.1

Bartov, E., Givoly, D., \& Hayn, C. (2002). The rewards to meeting or beating earnings expectations. Journal of Accounting and Economics, 33(2), 173-204. https://doi.org/10.1016/S0165-4101(02)000459

Carmona, P., Momparler, A., \& Lassala, C. (2015). The relationship between non-audit fees and audit quality: dealing with the endogeneity issue. Journal of Service Theory and Practice, 25(6), 777-795. https://doi.org/http://dx.doi.org/10.1108/MRR-09-2015-0216

Chen, H., Tang, Q., Jiang, Y., \& Lin, Z. (2010). The role of international financial reporting standards in accounting quality: Evidence from the European Union. Journal of International Financial Management and Accounting, 21(3), 220-278. https://doi.org/10.1111/j.1467-646X.2010.01041.x

Chen, S., Sun, S. Y. J., \& Wu, D. (2010). Client importance, institutional improvements, and audit quality in China: An office and individual auditor level analysis. Accounting Review, 85(1), 127-158. https://doi.org/10.2308/accr.2010.85.1.127

Cohen, J., Krishnamoorthy, G., \& Wright, A. M. (2002). Corporate governance and the audit process. Contemporary Accounting Research, 19(4), 573-594. https://doi.org/10.1506/983M-EPXG-4Y0RJ9YK

Aliyu, M.D., Musa, A.U., \& Zachariah, P. (2015). Impact of audit quality on earnings management of listed deposit money banks in Nigeria. Journal of Accounting and Finance Management, 1(4), 31-46. Opgehaal van www.iiardonline.org

DeFond, M., \& Zhang, J. (2014). A review of archival auditing research. Journal of Accounting and Economics, 58(2-3), 275-326. https://doi.org/10.1016/j.jacceco.2014.09.002

Eriabie, S., \& Dabor, E. L. (2017). Corporate governance and audit quality in Nigeria: Evidence from the banking industry. Journal of Accounting, Finance and Auditing Studies, 3(1), 1-16.

Franke, R.M., Johnson, M.F., \& Nelson, K. K. (2002). The relation between auditors' services and for nonaudit earnings management. The Accounting Review, 77(Supplement), 71-105. https://doi.org/10.2307/3203326

Gao, H., \& Huang, J. (2016). The even - odd nature of audit committees and corporate earnings quality. Journal of Accounting, Auditing \& Finance, 31(4), 1-25. https://doi.org/10.1177/0148558X15625438

Gaynor, L. M., Kelton, A. S., Mercer, M., \& Yohn, T. L. (2016). Understanding the relation between financial reporting quality and audit quality. Auditing: A Journal of Practice \& Theory, 35(4), 1-22. https://doi.org/10.2308/accr-50982

Gujarati, D. N. (2004). Basic econometrics - Economic series McGraw-Hill international editions: 
Economic series. ... Econometrics. https://doi.org/10.2307/2344828

Herath, K. S., \& Albarqi, N. (2017). Financial reporting quality: A literature review School. International Journal of Business Management and Commerce, 2(2), 1-14.

Hoitash, R., Markelevich, A., \& Barragato, C. A. (2007). Auditor fees and audit quality. Managerial Auditing Journal, 22(8), 761-786. https://doi.org/10.1108/02686900710819634

Kim, Y., Liu, C., \& Rhee, S. G. (2003). The relation of earnings management to firm size. Working Paper, University Of Hawaii., (1999), 1-30.

Knechel, W. R., Mintchik, N., Pevzner, M., \& Velury, U. (2018). The effects of generalized trust and civic cooperation on the big $\mathrm{N}$ presence and audit fees across the globe. Auditing A Journal of Practice \& Theory, January 20. Retrieved from https://doi.org/10.2308/ajpt-52014

Kothari, S. P., Leone, A. J., \& Wasley, C. E. (2005). Performance matched discretionary accrual measures. Journal of Accounting and Economics, 39(1), 163-197. https://doi.org/10.1016/j.jacceco.2004.11.002

Leung, S. C. M., Srinidhi, B., \& Xie, L. (2017). Auditor tenure , information asymmetry and earnings quality auditor tenure, information asymmetry and earnings quality. Working Paper, a Department of Accountancy, City University of Hong Kong, The University of Texas at Arlington, United States College of Economics, Shenzhen University, China Center for Finance and Accounting Research, Shenzhen University, China, March, 1-54.

Mitra, S., Deis, D. R., \& Hossain, M. (2009). The association between audit fees and reported earnings quality in pre- and post- Sarbanes-Oxley regimes. Review of Accounting and Finance, 8(3), 232-252. https://doi.org/http://dx.doi.org/10.1108/MRR-09-2015-0216

Ndubuisi, A. N., \& Ezechukwu, B. O. (2017). Determinants of audit quality: Evidence from deposit money banks listed on Nigeria stock exchange. International Journal of Academic Research in Accounting, Finance and Management Sciences, 7(2), 117-130. https://doi.org/10.6007/IJARAFMS/v7-i2/2877

Nelson, S. P., \& Devi, S. (2013). Audit committee experts and earnings quality. Corporate Governance, 13(4), 335-351. https://doi.org/10.108/CG-02-2011-0009

Okolie, A. O. (2014). Auditor tenure, auditor independence and accrual - based earnings management of quoted companies in Nigeria. European Journal of Accounting Auditing and Finance Research, 2(2), 63-90. Retrieved from http://www.eajournals.org/wp-content/uploads/Auditor-Tenure-AuditorIndependence-and-Accrual---Based-Earnings-Management-of-Quoted-Companies-in-Nigeria.pdf

Pfeffer, J., \& Salancik, G. (2003). The External Control of Organizations: A Resource Dependence Perspective. California: Stanford University Press.

Sun, J., Liu, G., \& Lan, G. (2011). Does female directorship on independent audit committees constrain earnings management? Journal of Business Ethics, 99(3), 369-382. https://doi.org/10.1007/s10551010-0657-0

Tang, Q., Chen, H., \& Lin, Z. (2016). How to measure country-level financial reporting quality? Journal of Financial Reporting and Accounting, 14(2), 230-265. https://doi.org/http://dx.doi.org/10.1108/MRR09-2015-0216

Turpen, R. A. (1995). Audit fees - what research tells us. (Auditing). The CPA Journal Online. Retrieved from http://archives.cpajournal.com/old/16349305.htm 